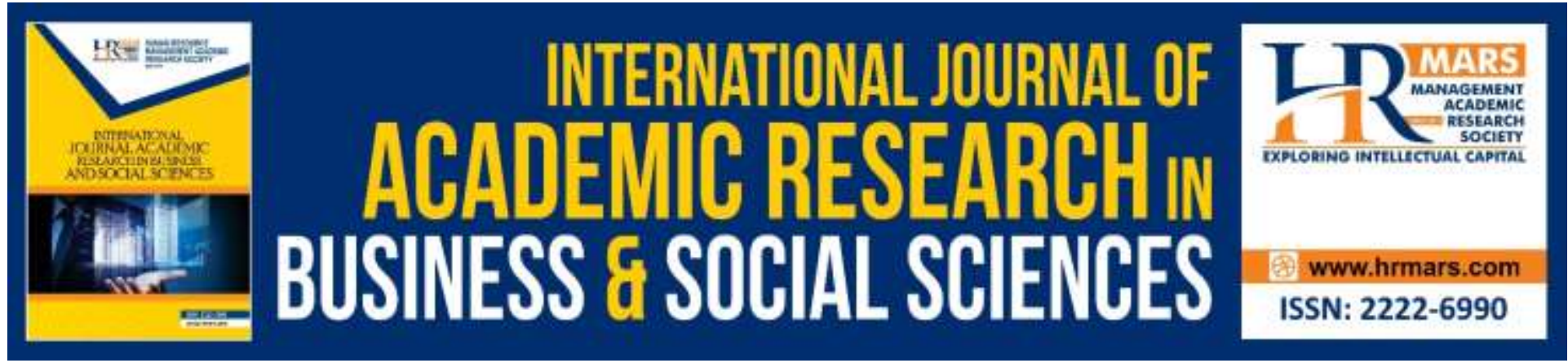

\title{
The Concept of Islamic Personality and Spiritual Development
}

\author{
Azimah Abdullah, Mohd Farid Mohd Sharif
}

To Link this Article: http://dx.doi.org/10.6007/IJARBSS/v9-i9/6383

DOI: $10.6007 /$ IJARBSS/v9-i9/6383

Received: 22 July 2019, Revised: 19 August 2019, Accepted: 29 August 2019

Published Online: 14 September 2019

In-Text Citation: (Abdullah \& Sharif, 2019)

To Cite this Article: Abdullah, A., \& Sharif, M. F. M. (2019). The Concept of Islamic Personality and Spiritual Development. International Journal of Academic Research in Business and Social Sciences, 9(9), 936-949.

Copyright: () 2019 The Author(s)

Published by Human Resource Management Academic Research Society (www.hrmars.com)

This article is published under the Creative Commons Attribution (CC BY 4.0) license. Anyone may reproduce, distribute, translate and create derivative works of this article (for both commercial and non-commercial purposes), subject to full attribution to the original publication and authors. The full terms of this license may be seen at: http://creativecommons.org/licences/by/4.0/legalcode

Vol. 9, No. 9, 2019, Pg. 936 - 949

http://hrmars.com/index.php/pages/detail/IJARBSS

JOURNAL HOMEPAGE

Full Terms \& Conditions of access and use can be found at http://hrmars.com/index.php/pages/detail/publication-ethics 


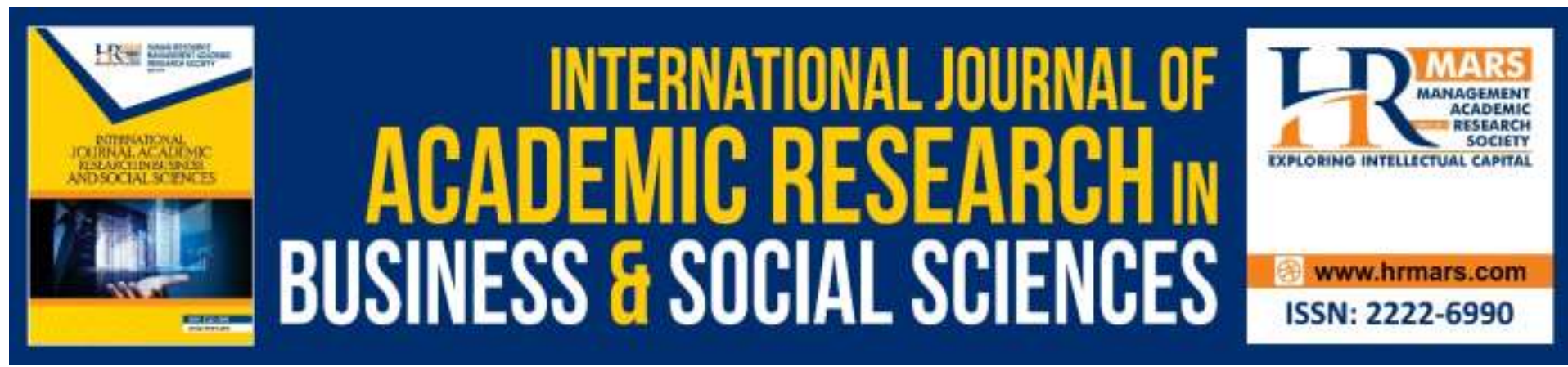

\title{
The Concept of Islamic Personality and Spiritual Development
}

\author{
Azimah Abdullah ${ }^{1}$, Mohd Farid Mohd Sharif ${ }^{2}$ \\ ${ }^{1}$ Universiti Sains Malaysia, Penang, Malaysia, \\ Email: danishhafiyya@gmail.com \\ 2Universiti Sains Malaysia, Penang, Malaysia, Email: faridusm@usm.my
}

\begin{abstract}
This paper aims to discuss and analyze the concept of development of Islamic personality and spirituality. Nowadays, the morality issues are increasing in the society. The unpredictable personality and spirituality of human beings have called for various social illnesses as reported in the previous study of Yusoff, Othman, Abdullah, Omar, N. and Omar (2018), Tunggak, Ngadi and Naim (2015), Ahmad, Don, Abdullah, Ibrahim and Hussain (2014), Kadir, Paad and Ghapar (2013) and others. This study however focuses on the concept of development of Islamic personality and spirituality from the Islamic scholars for instance al-Ghazali, Hawwa, Raiya and others which analysed to present the full explanation of the concept. The study employs qualitative research method - the data of the study is gathered from both hard and online materials, and analysed through typical qualitative analysis method: inductive and deductive. The findings of the study shows that the combination of faith, knowledge, charity and the process of tazkiyah al-nafs, mujahadah al-nafs and riyadah al-nafs implemented through the effort of struggle, patience, consistent with continuous routine of righteousness becomes the best possible way to uplift the strength of the human character and spirituality. This leads one to achieve the state of happiness. It also shows that when one gains the best condition of personality and spirituality that situation will lead a person not susceptible to outside influence or disturbance.
\end{abstract}

Keywords: Development, Personality, Spirituality, Perspective, Islamic Thought

\section{Introduction}

Islam is a universal and complete religion which covers the whole aspects of a person's life. Development in Islam emphasizes on the integrated and holistic aspects of development which include the spiritual, physical, life, afterlife aspects (Hamat and Nordin, 2012). Islam's objective of the wellbeing in life and afterlife emphasizes on the personality formation and education which is done in proportion and as a whole that do not only include the person's physical and spiritual aspects, but also emotional, intellectual and social aspects because the balance of the spiritual, physical and intellectual aspects is the important foundation of personality development. Therefore, personality development in Islam as visualised in the Quran and hadith will produce a kamil (perfect) person who is able to face and deal with 
current challenges. Besides, the aspects of knowledge development and formation of mahmudah (admirable) behaviour that are aligned with the suggestions in Islam and the teachings of the Prophets a.s are also important agendas of a person's personality development according to Islam. Lastly, it can contribute to the stability and harmony of the development, socially, culturally, politically (Ismail 2015), as well as strengthen the economy of a country (Makhbul, Yussof and Awang, 2015).

\section{Problem Statement}

The word "pernyataan" (statement) originates from the word "nyata" which means clear. "Pernyataan" is defined as declaration, announcement or disclosure. Meanwhile, problem is defined as a subject or something that has to be solved or a situation that causes difficulties (Dewan 2016). From those definitions, it can be understood that a problem statement is a declaration of a subject that needs to be solved. The problem statement of this research is focused on the symptoms of personality breakdown amongst youth that are spiritually related.

Hence, the problem statement of this paper started with the research by Kadir, Paad and Ghapar (2013) that presented the report from Malaysian Foundation of Crime Protection revealed several social offenses involving youth like misusing of drugs, truancy, street racing and dumping of babies. Meanwhile Abdullah (2010) found out that during the period of 10 years from the year 2000 to the year 2010, a total of 150 researches about several social delinquencies had been done. The research done by Sharif and Roslan (2011) that reported on delinquent (according to Kamus Dewan (2016) delinquent was defined as doing something that is against social norms or rules and the law which is not serious) behaviour amongst youth was in line with the research of Tunggak, Ngadi and Naim (2015) which also reported on the same cases involving primary and secondary school students. In the same year, Malaysian Education Ministry released data of 28,843 primary school students and 78,348 secondary school students involving in offenses that are criminal in nature, indecent, vandalism etc. Ahmad, Don, Abdullah, Ibrahim and Hussain (2014) also reported on the involvement of teenagers and youth in several personality breakdown symptoms like cohabitating, adultery, incest, baby dumping etc. Following that, based on the official report that was presented by Rashid and Hamid (2014) from the National Registry Department, as many as 167,073 births out of wedlock had been recorded from the year 2008 to the year 2012. The research was further supported by Abdullah, Ghani and Sipon (2014) who reported on the data increase of teenage pregnancy at the early age of 10 to 19 in 2012. Muda, Hamid, Rashid, Bakar and Azmi (2015) also presented personality offenses like adultery, incest, inappropriate behaviour in public and so on. On the other hand, Taniapa's research reported on the frequency of cases categorised as heavy disciplinary problems such as criminal, vandalism and other cases besides light disciplinary cases that occurred amongst students aged 13 and 14 at a school in Perak (Taniapa 2015). Meanwhile, Yusoff, Othman, Abdullah, Omar, and Omar (2018) reported that based on the information obtained from the National Anti-Drug Agency (AADK), for the year 2015, there are 20,289 recorded drug addicts and 23.92\% of drug addicts had been found. According to the data obtained from AADK official website (Statistik Dadah AADK 2019), the number of addicts traced throughout the country according to the status of the case had increased yearly from 20,887 addicts in 2013 to 25,922 in 2017. 
Research done by Muda, Hamid, Rashid, Bakar and Azmi (2015) and the research of Rahman and Stapa (2013) proved that social breakdown symptoms that have spread amongst Muslims are originated from the negligence of a human's spiritual aspect. Whereas, Marzuki, Rahman and Ismail (2019) found that the social symptom crisis that happens amongst youth in this country is related to the issues of personality and individual character.

\section{Research Questions}

The research questions of this research include: how is the concept of personality and spiritual development according to Islam? How is the concept of personality and spiritual development according to Muslim scholars?

\section{Purpose of the Study}

The purposes of this study include: to study the concept of personality and spiritual development according to Islamic perspective; to analyse the concept of personality and spiritual development according to Muslim scholars.

\section{Research Methods}

According to Dewan (2016), "metodologi" (methodology) is a system that encompasses the principal and method that are applied to a discipline, activity and so on. Meanwhile, research is defined as an activity that involves the effort or process of researching. Therefore, research methodology can be defined as a system used in the process of researching something. This research is a qualitative study that collects data and analyses the data using the following methods:

\section{Data Collection}

Literature Method

The word "Metod" (method) is translated as a system that is applied in doing something. Meanwhile, "kepustakaan" (literature) means a list of books used to compose and others, bibliography or all books (publications, literary works, and others) about a certain knowledge and so on (Dewan 2016). Therefore, a literature study is understood as an activity that involves the process of researching an information which is needed through several reference resources such as books, theses, journals etc. This study uses the literature method. The information chosen regarding the issue of the study is valued, analysed, synthesised, clarified, elaborated and summarised.

\section{Analysing Data}

Inductive Method

The inductive method is a way to draw a conclusion based on specific evidences to find a general conclusion (Dewan, 2016). All data from the reference materials will be analysed to get the real conclusion.

Deductive Method

The deductive method is a way to draw a conclusion based on general evidences and they are later elaborated in detail until they become specific and clear (Diah 1987; Dewan, 2016). All data and general information obtained will be analysed to get a more specific conclusion. 


\section{Findings}

Before presenting the findings, the meanings of a few words such as "pembangunan" (development), "sahsiah" (personality) and "kerohanian" (spiritual) need to be understood. According to Dewan (2016), the word "pembangunan" means the effort to achieve progress or advancement. "Sahsiah" means character or characteristic that is a trait, nature or specific features that are embedded in someone. Meanwhile, "kerohanian" is defined as a situation or subject relating to the spirit or spiritual characteristics (Dewan, 2016). Islam is a religion that really emphasizes on the personality and spiritual development of a person. One of the early strategies used by Rasulullah p.b.u.h after the Companions embraced Islam was to strengthen their spirits because a strong spirit can create a great personality.

When discussing about the personality and spiritual development of a person, most Muslim scholars, both classic and contemporary, started their discussion by analysing and focusing on questions regarding the heart and soul, because according to Islamic Relief Worldwide (2014) as well as Mokhtar, Fuad, Sa'ari dan Aini (2017), the spiritual development of a person is based on the development of the heart which is the catalyst for the personality formation of a person. The development of a person in Islam is related to the term tazkiyyah (cleansing/purifying) which is referred to the growth and cleasing of a person physically, mentally and spiritually in terms of the person's relationship with God, himself, society and nature (Mokhtar, Fuad, Dan Aini, 2017). The Islamic Relief Worldwide (2014) put high confidence that a person's hollistic development can be achieved by combining five harmonised dimensions known as maqașid (objective) of behaviour and Islamic law consisting of faith (iman), life, intellect, lineage and property. Faith is an important asset in handling weakness and difficulty because faith can assist in increasing the moral or personality of a person and guarantee social unity. The mind that is awarded to a person works as a center of knowledge. The mind and knowledge are the cores of a person's development (Islamic Relief Worldwide, 2014).

In examining the issues of personal development and spirituality, a few guidelines in developing a person's personality and spirit were presented by a few scholars in Sufism such as al-Ghazali (d. 505H/1111M) (Syeikh, 1974; Akhir, 2008), al-Qushayri (d. 465H/1072M; His full name was Abu al-Qasim 'Abd al-Karim bin Hawazin al-Qushayri. He was a sufi scholar educated in the law of Syafii madhhab and Ash'ariyah theology) (Mojaddedi, 2000) and alSuhrawardi (d. 587H/1191M; Marcotte (2001) mentioned his name as Yaḥya Ibn Ḥabash Ibn Amirak Abu al-Futuh Shihab al-Din al-Suhrawardi. Jurji (1940) reported his name as Abu alFutuh Yahya al-Suhrawardi. Born in an Iranian village situated in the northwest of Suhraward, Iran around 1154AD. Received early education in Islamic philosophy and law. Said to be the follower of Syafii madhhab. Used to live and receive education in Maraghah, Ișfahan and Baghdad. Later, he moved to Aleppo in 1183AD during Ayyubiyah's government which was when al-Zahir (died 1216M) was governing. He was known as shaykh al-ishraq or "The Master of Illumination" because he introduced the metaphysic theory of illumination. His most important work was "The Philosophy of Illumination") and others which starts with the process of tazkiyah al-nafs (purifying or cleansing of the soul). The tazkiyah al-nafs process involves al-takhalli and al-tahalli operations. Al-takhalli or mujahadah al-nafs is a process that is able to eliminate and cleanse the soul from blemished characteristics which are categorized as madhmumah behaviour that can tarnish the heart. Then, the soul will be filled and adorned with admirable and noble characteristics which are mahmudah behaviour through the process of al-tahalli or riyaḍah al-nafs (Yasin, 1997; Zahri, 1984). Both of the processes are 
able to help solve life problems of a person, consequently guarantee the happiness and wellbeing in life and afterlife (al-Ghazali 1983) because the purpose of development in Islam is to gain success (al-falah) which is the success and wellbeing of life and afterlife that includes fulfilling the demand of a person's physical and spiritual balance (Mohamad and Ahmad, 2013).

In the analysis done by the contemporary muslim scholar, Raiya (2012), regarding the theory of al-Ghazali's human's personality and spiritual development, he stated that human beings are equipped with spiritual elements consisting of al-qalb (heart), al-nafs (soul), al-ruh (spirit)

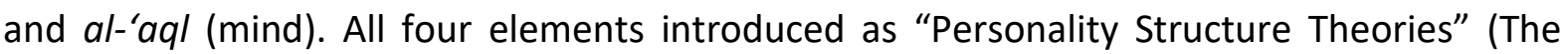
"Personality Structure Theories" are based on the Islamic belief and philosophy that refer to the Quran. Al-Ghazali was in the opinion that a person's personality is arranged according to four psychosexual structures which are qalb (heart), spirit (morale), nafs (soul) and 'aql (intelect). These structures interact dinemically and the outcome will produce the spiritual wellbeing of a person. Qalb is the most important content of nafs compared to other personality structures because the main process of a person happens at the qalb. Qalb is also the human's essence including a human's knowledge, thinking and understanding. However, the spirit is located in the qalb. Raiya presented two meanings of nafs according to al-Ghazali, firstly; nafs means the whole person and secondly it means the inner part of a human that is responsible for desires, primitive emotions such as anger and qualities that are not wanted by a person. The second meaning of nafs is more common among mystic. ' $A q l$ is higher compared to the personality. According to al-Ghazali ' $a q /$ has an angelic element and works intelectually) are the nature or identity of every person (al-Ghazali 2001; Akhir 2008; Hamjah 2010). Three of the personality structures according to the Quran as presented by him that are known as "The Qura'nic Structure Personality" consist of al-nafs al-ammarah bi al-su' (one's self), al-nafs lawwamah (desire that blames one's self) and al-nafs al-muțma'innah (calm desire) (Raiya 2012). All three categories of desire were also discussed by Karim (t.t), Hawwa (2006) and Akhir (2008). However, Raiya (2012) added another category of al-nafs known as al-nafs al-marid (ill desire), which reffered to by al-Ghazali (1998) as asqam al-nufus (ill lust), as a result of qalb that is closed and contrary to good characteristics. Raiya (2012) summarized eight main concepts of the personality theory which are related to one another according to the Quran, which are:

Nafs means personality or the whole person including all other personality structures.

The most influential and evil desire is al-nafs al-ammarah bi al-su'. This desire that is devilish (the term devilish was also used by Karim (t.t) when discussing natures of men). and strongest amongst nafs is classifed as unconcious desire and more proned to do profihibited things.

The desire that has an origin and influence from God besides having moral entity is known as al-nafs al-lawwamah. This desire works as an instinct and is unconcious.

The soul (al-ruh) is collectively unconscious. The soul works as an inspiration. This creation or source of revelation probably means the truth or energy of life.

'Aql that is a component of the concious system and has angelic nature, has a role to know God's manifests through human beings and the nature. Besides that, the 'aql also works as a intelectual faculty of the nafs towards a high cognitive process that includes thinking, knowing, reflecting and understanding.

Qalb that is the heart of the nafs or the whole nafs becomes the center of information collection, combination and process and the input from all other nafs structures. Ultimately, it will determine nafs' position as good or the opposite. 
Al-nafs al-muțma'innah is the best and most desirable nafs. This nafs is the outcome of active and dynamic connections of several nafs elements.

Al-nafs al-marid as described previously.

Qalb is the core system that is related to other components. All processes of integration amongst the 'aql, soul and qalb will react to al-nafs and eventually produce good or bad behaviour (Raiya, 2012).

Al-Ghazali (1983) himself strongly believes that a person's happiness is gained through tazkiyah al-nafs and its perfection. One of the practical knowledge emphasized by him is the knowledge of the soul (nafs) such as its characteristics and behaviour. This knowledge is applied through practice (riyadah) and the battle against desires (mujahadah al-hawa). Mujahadah and riyadah that are mentioned by al-Ghazali (1983) as al-quwa (strength) which are performed through good deeds, are two methodologies recommended by him in the process to change and shape behaviour and treat desires. Those two approaches are believed to be able to cleanse and complete the soul in the context of behaviour shaping, because the cure to eliminate illness, subsequently gaining health and goodness relating to the spirit and bettering the personality is by treating the soul. The health of the soul is very important and needs to be taken care of because a pure and clean soul will produce decent behaviour (alGhazali, 1983). Al-Ghazali's opinion was agreed by Hawwa (2006) who set high expectations that a person's personality and spiritual development can be realised through the soul purifying process (tazkiyah al-nafs) which is by managing the soul (mujahadah li al-nafs). Hawwa (2006) presented mujahadah in thinking about the soul (al-nafs) and heart, or ilnesses of the both and the way to cure them is one of the main aspects of mujahadah, as a way to cure and prevent illnesses of the soul. The soul purifying process that is applied through spiritual practises (daurah) is believed to be able to strengthen the faith while curing and preventing all illnesses relating to the heart and soul of a person.

Al-Ghazali (1983) himself had given emphasis to three aspects of strength that need to be cleansed which are the strength to think (quwwah al-tafakkur), the strength of lust (quwwah al-shahwah) and the strength of anger (quwwah al-ghadab). Knowledge of 'hikmah' (intelligence) as explained by Allah S.W.T in the meaning of surah al-Baqarah verse 269: ("He gives wisdom to whom He wills, and whoever has been given wisdom has certainly been given much good. And none will remember except those of understanding.") will be achieved when the strength to think is cleansed and corrected according to fate. Lust on the other hand, if managed, then 'iffah behaviour (avoiding dubious and unlawful subjects) can be achieved. As a result, desire can be prevented from doing bad things and otherwise will be encouraged to do noble things. Meanwhile, when the strength of anger is overcome and fixed, then the decency to control the needs of the desire and to overcome anger will appear. Lastly, bravery (al-shaja'ah) will be achieved when the desire from fear and greed is managed. Following that, when the strength to think, the strength of lust and anger are corrected and controlled, then balance will be achieved (al-Ghazali, 1983).

Al-Ghazali (1983) emphasized that the nafs and the body are related and influence one another. Therefore, a complete and pure soul is able to create a good, beautiful and blessed reaction. Hence, a person needs to familiarise himself with behaviour that come from a pure and complete soul until it becomes a norm or habit. Mujahadah, riyadah and the consistent, continuous and long-term care of desires can strengthen a person's identity because the way to purify the soul is through good deeds and the purity of the soul is the key to gain perfection. Sufism behaviour as introduced by al-Ghazali (1983) becomes the priority in the formation of 
a human being towards achieving happiness and success in the ukhrawi life. Al-Ghazali (1983) explained that happiness is gained through the cleansing and perfection of the soul by achieving the soul's priorities, which are; (i) The mind's quality and difference (judah al-dhihn wa al-tamyiz) that can differentiate between the path towards happiness and suffering and practise with the path of happiness. (ii) The beauty of behaviour (husnu al-khuluq) that is gained by eliminating all bad habits as guided by religion. Among four domains of the soul's priority towards achieving happiness as discussed by al-Ghazali (1983) are intelligence (alhikmah), bravery (al-shaja'ah), self preservation (al-'iffah), and balance (al-'adalah). Alhikmah and al-shaja'ah are the priorities for the strength of anger (al-quwwah alghadabiyyah). Al-'iffah is the priority for the strength of the mind (al-quwwah al-'aqliyyah). Al-shaja'ah is also the priority for the strength of lust (al-quwwah al-shahwaniyah). Meanwhile, al-'adalah happens when all of the three quwa follow the appropriate commands or become organised. MZ (2018) defined all four priority domains of the soul as the priority principle of behaviour that has potential to develop good behaviour from all aspects. He said that the meaning of al-hikmah according to al-Ghazali (1983) is the condition of the soul that can be used to handle lust, manage anger and encourage it to follow hikmah's needs. Alhikmah is also one of the priorities of a rational soul that is able to differentiate between fact and fiction, while preserving the soul. Meanwhile, the second al-hikmah is hikmah khuluqiyah that is the behaviour and priority of a mindful soul. That soul can manage the strength of lust and anger, besides controlling its movement in a happy and sad situation ( $M Z 2018$ ).

Based on the analysis done by MZ (2018) on al-Ghazali's priority domains of the soul, MZ was in the opinion that al-shaja'ah is one of the behavioural priorities that is very noble and admirable. That characteristic is needed to fight against fraud, untruth and cruelty that was done. Al-'iffah on the other hand is one of the elements of a good personality that includes continuous effort in caring of self, religion, honour, dignity and properties which has a role in neutralising despicable characteristics such as the weakness and excessive of lust until it becomes a noble charateristic. Al-'adalah is the balance that happens when al-hikmah, alshaja'ah and al-'iffah are arranged and suitable with the supposed arrangement. Al-'adalah is the basic principle of behavioural education. Al-hikmah, al-shaja'ah, al-'iffah and al-'adalah are al-Ghazali's priority principle of behaviour referring to good behaviour (akhlaq alkarimah) with reference to the Quran. $\mathrm{MZ}$ (2018) was convienced that every person is able to practise noble behaviour as taught by al-Ghazali if done with an effort involving the physical and spiritual aspects. According to $M Z$ (2018), the priority principle of behaviour that was introduced by al-Ghazali really emphasizes on the aspect of perservation of the soul's safety in forming a person's personality and spirit.

MZ (2018) also supported al-Ghazali's view by stating that the formation of a noble personality must be done by cleansing the soul which includes the processes of mujahadah and riyadah, especially in controlling and managing emotion and lust. This is because according to al-Ghazali (1983), behaviour can be changed through continuous learning process and soul practice towards actions that encourage good behaviour (al-Zabidi t.t; MZ, 2018). Mujahadah and riyadah are some of the keys to achieve nobility of behaviour that should be done forcefully by obligating and getting self used to doing good acts besides being patient at all times (MZ, 2018). A few methodology of personality development according to al- Ghazali that are also discussed by MZ (2108) are; (i) giving effort, istiqamah and continuous in carrying out mujahadah and riyaḍh (ii) always observe and evaluate self into doing good deeds based on knowledge gained or through experiences of surrounding people (iii) 
muhasabah al-nafs (evaluating one's self) to see the weakness of self and consequently better the behaviour (iv) fight against all extreme desires by carrying out good deeds, and (v) always be in a good surrounding or situation to familiarise with the situation until it becomes embedded in self. One of the regulations to gain good or noble behaviour is through the processes of mujahadah al-nafs and riyadah al-nafs coupled with a high determination in obligating or forcing self and getting self used to carrying out the process. Even so, MZ (2018) added a third regulation, which is (iii) having high detemination to leave all lusty desires which can lead to the extremely seeking of worldly pleasures. Besides, MZ (2018) stated that other than persistence (istiqamah), patience is also a key to success in going through the process. The best approach to treating and curing the soul is by eliminating all depravities and despicable behaviour, besides nourishing self with all nobilities and admirable behaviour because the perfection of the soul is achieved through knowledge, practice and good behaviour. The behavioural goal as discussed by MZ (2018) is precised with al-Ghazali's view that in order to shape an inner behaviour or personality that influences the production of soul priority which is able to achieve happiness as mentioned by al-Ghazali as being the true happiness (al-sa'adah al-haqiqiyah). The true happiness is focused on behaviour that becomes a person's priority evaluation basis or greatness. The soul's priority or greatness on the other hand is a way to achieve calmness of the heart or soul which becomes a person's life goal to gain happiness in life and afterlife. The concept of behaviour development as recommended by al-Ghazali also has the goal to achieve paradise and to get human closer to Allah S.W.T as guided by the Quran and the Sunnah (MZ, 2018).

Saruhan (2010) agreed with al-Ghazali by being confident with the strict practice (riyazah) to control's someone's desires and trying hard to fight against lust (mujahadah) can achieve moral perfection or good behaviour as recommended by the religion. According to Saruhan (2010), moral life involved a person's fight against himself that is applied continuously. While analysing al-Ghazali's view regarding a person's mujahadah, Saruhan (2010) was in the opinion that there are three categories of human which are; (i) those who are beaten by their corporeal desires and lusts, (ii) those who continue to struggle against them and (iii) those who have won over them. The way to achieve perfection is through knowledge that helps a person to gain knowledge about Allah S.W.T and the freedom that saves a person from being overpowered by lust and the world. According to Ogunbado, Ahmed and Daud (2016), knowledge is the important basis in the process of personality development or a person's personality. Allah S.W.T wants human to develop their personality intelectually and Allah S.W.T heightens the personality of Prophet Adam a.s through knowledge. Personality and spiritual development based on knowledge is done in stages starting with children at an early age of seven. Besides that, Ogunbado, Ahmed and Daud (2016) recommended modesty in the aspect of personality development of a person, for example having bravery.

A person's personality development according to al-Muhasibi (d. 243H/857AD; a sufism scholar who also pursued the knowledge of fiqh, Quran, language, theology, tasawwuf and hadith) is based on the spiritual development because the reason immoral acts happen is a person's heart and soul that do not have spiritual strength. As a result, the heart is easily influenced and overpowered by nafs al-ammarah that may create several spiritual illness phenomena such as madhmumah trait or bad behaviour (Rahman and Stapa 2013). The spiritual concept of al-Muhasibi that contributes to the development of a person's personality and is based on the spiritual education was also discussed by Hassan, Salleh, Zain and Hamzah (2011). The spiritual education process of al-Muhasibi is in line with the process of tazkiyah 
al-nafs al-Ghazali which contributed to a person's personality development (Mohamad, Hamjah and Mokhtar 2017). Al-Muhasibi also outlined three main processes of spiritual development such as those presented by al-Ghazali, which are muhasabah al-nafs (muhasabah or soul evaluation) (Hassan, Salleh, Zain and Hamzah 2011), mujahadah al-nafs and riyadah al-nafs. According to al-Muhasibi, muhasabah al-nafs is the process of bettering the soul by seeing, watching, analysing the whole condition of the soul and actions in a person's daily life, besides identifying the cause of negligence and disobedience (Rahman and Stapa 2013; Che Kasim 2000). The muhasabah al-nafs process can be done using two methods which are; (i) muhasabah of actions taken by reflecting and learning lessons from the actions that have been taken. The soul is guided to regret vice and sins commited and repent quickly to God (ii) muhasabah on actions that might take place by observing and analysing the actions of the soul so that decisions are not made or actions are not taken in haste. This method needs to be realised according to knowledge so that a person can make the right decision between good and bad (Rahman and Stapa 2013). Meanwhile, the mujahadah al-nafs and riyadah al-nafs processes must be carried out by consistently fighting desires. According to Mohamad, Hamjah and Mokhtar (2017), in general, tazkiyah al-nafs concept that emphasizes on the spiritual aspect as presented by al-Muhasibi is seen as a form of prevention (alwiqayah), treatment (al-ilaj) and development (al-tanmiyah). Acccording to them, prevention is carried out through the process of mujahadah al-nafs and patience is needed when carrying out mujahadah al-nafs. A person that is patient for Allah's sake can face all bad tricks of the desire. Al-tanmiyah is a process of self development with consistent desirable deeds and characteristics. The main thing that must be done in developing an excellent soul is by carrying out the compulsary deeds as instructed by Allah S.W.T followed by sunnah deeds. These deeds need to be done with full sincerity for Allah S.W.T (Mohamad, Hamjah and Mokhtar, 2017).

\section{Conclusion}

The personality and spiritual development of a person is highly emphasized in Islam. Therefore, the discussion of the personality and spiritual development of a person amongst Muslim scholars, both classic and contemporary such as al-Ghazali, al-Muhasibi, al-Qushayri, al-Suhrawardi, Raiya and others started by studying the questions of a person's soul, because the spiritual development of a person that is based on the development of the heart, becomes the factor of the formation of a person's personality. Therefore, a few guidelines for personality and spiritual development start with the process of tazkiyah al-nafs were presented by al-Ghazali, al-Muhasibi, al-Qushayri, al-Suhrawardi and others. They agreed that the process of tazkiyah al-nafs is the main and best method to help a person cleanse and treat the soul from all illnesses regarding the spirit. By carrying out the process continuosly, patiently and consistently, spiritual illnesses will eventually be overcome and recovered. Next, it will produce good behaviour and distinctive personality in a person. Nevertheless, knowledge especially knowledge regarding the spiritual education becomes the main foundation to carry out the process of tazkiyah al-nafs. On the other hand, the processes that include mujahadah al-nafs and riyadah al-nafs have the potential to shape a person's personality and character.

This study uses the theory of text dealism as well as al-Ghazali's theory of personality and spiritual development. According to Mana Sikana (2015) and Abdul Halim (2011), the word text dealism comes from the words "text" and "idealism". The theory of text dealism or also 
known as the theory of excellence defines text as a set of experiences and ideas that contain a set of superior meanings. Excellence in authorship of a writer is achieved through wisdom and courage. Wisdom in authorship is based on knowledge and awareness. Courage is an open attitude to expressing thoughts and new ideas as well as being willing to make changes and innovations that influence the readers' perception, convention and status quo. However, al-Ghazali's theory of Islamic personality and spiritual development is based on his thought's as described such as in Ihya' 'Ulum al-Din and Mizan al-'Amal. Generally, this study contributes the development of superior personality as a result of strong spirituality. Based on the analysis of the concept of Islamic personality and spiritual development presented by the Islamic thinkers as discussed earlier, it can be concluded that the basis of the process of Islamic personality and spiritual development begins with the tazkiyah al-nafs. Meanwhile, tazkiyah al-nafs includes mujahadah al-nafs and riyadah al-nafs. For the maximum impact, the tazkiyah al-nafs process, which is based on science, especially psychoanalysis, should be carried out in a consistent manner, accompanied by a high degree of patience and continued throughout life. Finally, the process of tazkiyah al-nafs is believed to strengthen the spirituality of the individual as well as to produce individuals with the superior character as the process works to prevent, treat and develop an individual's inner self.

\section{References}

Abdullah, A. (2010). Tema dan isu penyelidikan mengenai gejala sosial pada dekad pertama abad 21 di Malaysia. Akademika 78, 8(5), 4-10. ejournals.ukm.my.

Abdullah, S., Ghani, S. A. \& Sipon, S. (2014). Harga diri remaja terlibat seks bebas. 'Ulum Islamiyyah: The Malaysian Journal of Islamic Sciences, 14, 19-42. http://ddms.usim.edu.my/handle/123456789/9165.

Ahmad, S., Don, Y., Abdullah, W. A. R. K. W., Ibrahim, M. M. \& Hussain, S. F. M. (2014). Penghayatan solat dan pengimarahan masjid: kajian dalam kalangan pelajar Universiti Utara Malaysia. Proceeding of the Social Science Research ICSSR 2014. http://worldconferences.net/proceedings/icssr2014/toc/papers_icssr2014/IC\%2021 6\%20Dr\%20Shukri\%20Ahmad.pdf.

Akhir, N. S. M. \& Sabjan, M. A. (2014). Pembangunan modal insan dari perspektif kerohanian agama: Islam sebagai fokus. Journal of Human Capital Development, 7(1), 33-47. http://journal.utem.edu.my/index.php/jhcd/article/view/2137/1284.

Akhir, N. S. M. (2008). Al-Ghazali and his theory of the soul a comparative study. Pulau Pinang: Penerbit Universiti Sains Malaysia.

Al-Ghazali, A. H. M. A. (1983). Mizan al-'amal. Bayrut: Dar al-Kitab al- 'Arabi.

Al-Ghazali, A. H. M. A. (1998). Ihya' 'ulum al-din. Jil. 3. Beirut: Dar al-Ḥadith.

Al-Ghazali, A. H. M. A. (2001). Ihya' 'ulum al-din. Jil. 3. Beirut: Dar al-Kutub al-'llmiyyah.

Ali, A. H. (2011). Proses kreativiti A.Samad Said berasaskan teori teksdealisme. Jurnal Melayu, (6), 153-168. http://journalarticle.ukm.my/2924/.

Al-Zabidi, M. M. H. (t.t). Ithaf al-sadah al-muttaqin bisharh ihya' 'ulum al-din. Jil. 7. t.tp: Dar al-Fikr.

Basmeih, A. M. (2010). Tafsir pimipinan al-Rahman. Kuala Lumpur: Darulfikir.

Dewan Bahasa dan Pustaka. (2016). Kamus dewan. Kuala Lumpur: Dewan Bahasa dan Pustaka.

Diah, A. H. M. (1987). Suatu contoh tentang huraian metodologi. Kuala Lumpur: Fakulti Usuluddin, Akademi Islam Universiti Malaya. 
eprints.um.edu.my/13070/1/9.pdf.

file:///C:/Users/Acer/Downloads/3920-10435-1-PB.pdf.

file://C:/Users/Acer/Downloads/AKHLAK_ISLAMI_PERSPEKTIF_ULAMA_SALAF\%20(1 ).pdf.

Hamat, M. F. \& Nordin, M. K. N. C. (2012). Akidah dan pembangunan modal insan. Universiti Malaya: Penerbit Universiti Malaya.

Hamjah, S. H. (2010). Bimbingan spiritual al-Ghazali dan hubungannya dengan keberkesanan kaunseling: satu kajian di pusat kaunseling Majlis Agama Islam Negeri Sembilan (PK MAINS). ISL MIYY T, 32(2010), 41-61. http://journalarticle.ukm.my/7495/1/18633547-1-SM.pdf.

Hassan, A. R. H., Salleh, A. H., Zain, K. A. M. \& Hamzah, W. N. (2011). Kamus bahasa Melayubahasa Arab bahasa Arab-bahasa Melayu. Shah Alam: Oxford Fajar Sdn. Bhd.

Hawwa, S. (2006). Pendidikan spiritual. Yogyakarta: Mitra Pustaka.

http://conference.kuis.edu.my/icpr/2014/eproceedings/3.\%20Azizah\%20Binti\%20M at\%20Rashid.pdf.

http://conference.kuis.edu.my/irsyad/images/eproceeding/2017/1099.pdf.

http://dx.doi.org/10.1080/13674676.2011.640622.

http://ejournals.ukm.my/jhadhari/article/view/12492/4036.

http://journal.kuis.edu.my/jsass/images/files6/jsass_vol4bil1_012_abudardaa.pdf . http://journalarticle.ukm.my/9531/1/3x.geografia-si-sept15-zafir_\%281\%29.pdf.

http://www.ukm.my/fep/perkem/pdf/perkemVIII/PKEM2013_2A3.pdf.

https://journal.unisza.edu.my/jimk/index.php/jimk/article/view/271/246 .

httpscore.ac.ukdownloadpdf11787495.pdf.

Islamic Relief. (2014). An Islamic perspective on human development. United Kingdom: Islamic Relief. Diperoleh dari https://jliflc.com/wp/wp-content/uploads/2014/07/HumanDevelopment-v3.pdf pada 25 Februari 2019.

Ismail, S. (2015). Pembangunan insan dalam falsafah pendidikan kebangsaan. Journal of Human Capital Development, 8(2), 83-99. journal.utem.edu.my.

Jurji, E. J. (1940). The israqi revival of al-Suhrawardi. Journal of American Oriental Society, 60(1), 90-94. doi: 10.2307/594566.

Kadir, F. A. A., Paad, N. S. \& Ghapar, M. N. A. (2013). Salah laku remaja dan asas penyelesaiannya menurut perspektif Islam. International Seminar on Islamic Jurisprudence in Contemporary Society (ISLAC 2013).

Kamus dewan. (2016). Edisi Keempat. Kuala Lumpur: Dewan Bahasa dan Pustaka.

Karim, M. F. U. (t.t). Imam Gazzali's ihya ulum-id-din book III. Pakistan: Masud Sarwar Sind Sagar Academy.

Makhbul, Z. M., Yussof, I. \& Awang, A. H. (2015). Antara realiti dan harapan - kajian empirikal persepsi majikan terhadap prestasi graduan tempatan. Malaysian Journal of Society and Space, 11(10), 27-36.

Marcotte, R. D. (2001). Suhrawardi al-maqtul, the martyr of Aleppo. Al-Qanțara XXII, 22(2), 395-419.

Marzuki, M. K., Rahman, M. M. A. \& Ismail, A. (2019). Pembentukan Sahsiah Pelajar dan Hubungannya Dengan Pelaksanaan Amalan Solat: Kajian Di Institusi Pengajian Tinggi (IPT) Kelantan. Jurnal Islam dan Masyarakat Kontemporari, 20(1), 49-65.

Mohamad, A. D., Hamjah, S. H. \& Mokhtar, A. I. (2017). Konsep tazkiyah al-nafs menurut alHarith bin Asad al-Muhasibi. Jurnal Sultan Alauddin Sulaiman Shah, 4(1), 115-125. 
Mohamad, N. S. \& Ahmad, S. (2013). Pembangunan menurut perspektif Islam: Satu analisis awalan. Prosiding Persidangan Kebangsaan Ekonomi Malaysia ke VIII (PERKEM VIII), 1, 356. Johor Bahru.

Mojaddedi, J. A. (2000). Legitimizing sufism in al-qushayri's "risala". Studia Islamica, 90(2000), 37-50. https://sci-hub.tw/10.2307/1596163.

Mokhtar, A. A., Fuad, Z., Sa`ari, C. Z. \& Aini, Z. (2017). Teori pembangunan hati menurut alSyaykh ibn 'Ata' Allah al Sakandariy. Persidangan Antarabangsa Pengajian Islamiyyat Kali Ke-3 (IRSYAD2017), 819-834.

Muda, T. E. A. T., Hamid, N. A. A., Rashid, M. A., Bakar, N. H. \& Azmi, N. (2015). WAR 08 kesalahan akhlak dan perkaitannya dengan faktor kematangan, kerohanian dan kesedaran kendiri individu. World Academic and Research Congress 2015 (WORLD-AR 2015), 69-80. rmc.kuis.edu.my/world-ar/wp-content/uploads/2015/11/WAR-08KESALAHAN-AKHLAK-DAN-PERKAITANNYA-DENGAN-FAKTOR-KEMATANGANKEROHANIAN-DAN-KESEDARAN-KENDIRI-INDIVIDU.

MZ, S. R. (2018). Akhlak Islami perspektif ulama salaf. Edukasi Islam, Jurnal Pendidikan Islam, 7(1), 67-100.

Ogunbado, A. F., Ahmed, U. \& Daud, B. A. (2016). The significance of Islamic spiritual ethics in human personality development. International Review of Management and Marketing, 6(S8), 119-124.

Rahman, N. A. \& Stapa, Z. (2013). Pembangunan kerohanian berasaskan al-Muhasibi dalam menangani gejala sosial masa kini. WCIK E-JOURNAL OF INTEGRATION KNOWLEDGE 2013.

https://worldconferences.net/journals/wcik/wcikv2/PEMBANGUNAN\%20KEROHANI AN\%20BERASASKAN\%20AL-MUHASIBI-\%20norfadilah.pdf.

Raiya, H. A. (2012). Towards a systematic Qura'nic theory of personality. Mental Health, Religion \& Culture, 15(3), 217-233.

Rashid, A. M. \& Hamid, N. A. A. (2014). Undang-undang jenayah syariah: suatu sorotan berhubung kesalahan akhlak. International Conference on Postgraduate Research 2014 (ICPR 2014). Malaysia: Kuala Lumpur.

Sharif, Z. \& Roslan, N. M. (2011). Faktor-faktor yang mempengaruhi remaja terlibat dalam masalah sosial di Sekolah Tunas Bakti, Sungai Lereh, Melaka. Journal of Education Psychology \& Counseling, 1, 115-140.

Sikana, M. (2015). Penulisan akademik sastera. Kuala Lumpur: Dewan Bahasa dan Pustaka.

Stanford University. (2007). Stanford Encyclopedia of Philosophy, Suhrawardi. Diperoleh dari https://plato.stanford.edu/entries/suhrawardi/\#Lif.

Statistik Dadah AADK. Diperoleh dari https://www.adk.gov.my/orang-awam/statistikdadah/.

Syeikh, M. S. (1974). Studies in muslim philosophy. Lahore: SH Muhammad Ashraf.

Taniapa, M. (2015). Analisis masalah disiplin berat dalam kalangan pelajar di sebuah sekolah menengah. Disertasi Sarjana, Universiti Perguruan Sultan Idris, Tanjung Malim. pustaka2.upsi.edu.my/eprints/1810/.

Tunggak, B., Ngadi, S. \& Naim, H. A. (2015). Delinkuen pelajar dan cadangan penyelesaiannya menerusi model pembangunan sahsiah remaja/pelajar muslim bersepadu. Jurnal Hadhari, 7(2), 11-30.

Yasin, M. S. (1997). Mengenal ilmu Tasawuf. Kuala Lumpur: Jabatan Kemajuan Islam Malaysia. 
Yusoff, M. A., Othman, M. S., Abdullah, R. T., Omar, S. M. H. S, Mohamad, N., Omar, S. H. S. (2018). Implementation of repentance: the basic changes in drug addicts. International Journal of Academic Research in Business and Social Sciences, 8, 706715. http://dx.doi.org/10.6007/IJARBSS/v8-i4/4054. 